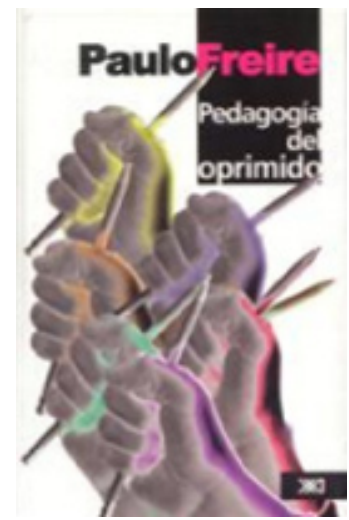

\section{Pedagogía del Oprimido} Paulo Freire Siglo XXI 2005

Veronika Rivero Veras. veronikk_@hotmail.com

Pedagogía del Oprimido, es un ensayo que muestra la importancia de la libertad del ser humano, la cual, según el autor, sólo se pude conseguir con una educación que ayude a la gente oprimida a liberarse.

Es un libro en el cual el autor te va llevando de un estado de frustración por la deshumanización de la sociedad, hasta un estado en el cual te incita a imaginarte como protagonista en el trabajo de la liberación de los oprimidos en contra de los opresores.

Este es un libro que sin duda todo Licenciado en Ciencias de la Educación tiene que leer, releer y volver a leer, ya que es un instrumento que la educación debe tener para lograr que la humanidad vuelva al camino de la humanización, y sobre todo de la liberación.

Debemos de considerar al libro Pedagogía del Oprimido, como una pedagogía humanista y liberadora, la cual cuenta con dos momentos distintos, el primero en que los oprimido descubren el mundo de la opresión y se van comprometiendo en la praxis con su transformación, y el segundo, en el que una vez que se trasforma la realidad opresora, esta pedagogía deja de ser del oprimido y pasa a ser la pedagogía de los hombres en el proceso permanente de la liberación.

\section{Los siete pecados capitales Fernando Savater Editorial Sudamericana, 2006}

Lizbeth Morales Cordero Lizbethm_c@yahoo.com

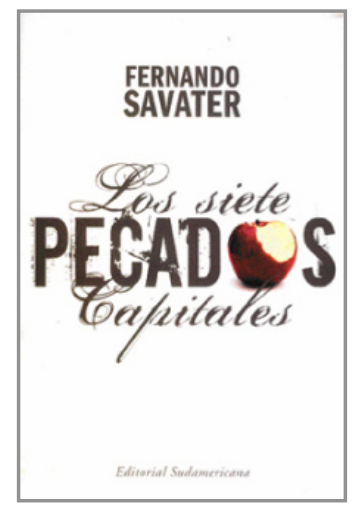

El tema central del libro gira en torno a los siete pecados capitales, los cuales, Fernando Savater describe de acuerdo al contexto en el que actualmente vivimos, y de acuerdo a la moral que hoy en día la sociedad posee.

En las primeras hojas del libro, el autor menciona que las personas viven gracias a los vicios, dentro de nuestra sociedad, una sociedad que describe como sociedad de consumo, en donde las personas solo buscan vender para darle gusto a las demás, de este modo las personas actúan por sus propios intereses sin darse cuenta que el único beneficiado en sus acciones es él mismo, y nadie más.

Fernando Savater establece el significado que tenía cada pecado en otros tiempos, pero que ahora se percibe de otra manera, aunque exista hoy en día la moda de los valores y la formación moral, en la realidad sólo se queda en la teoría y no se ve en la práctica.

Los siete pecados capitales que se encuentran claramente explicados son: el pecado de la soberbia, la gula, la avaricia, la ira, la lujuria, la pereza y la envidia.

El libro tiene una tendencia crítica moralista, debido a que la lectura hace una fuerte reflexión de las acciones que cometemos como seres humanos, es decir, como personas, es una lectura que nos hace reflexionar con un estilo particular que contagia el autor, acerca de nuestras acciones y de injusticias que cometemos con los demás y hasta con nosotros mismos.

La lectura se puede utilizar para esclarecer cada uno de los siete pecados capitales, puede ser una opción interesante para las materias de ética, en donde el objetivo principal es llevar al alumno a una conciencia justa. 